\title{
TRANSCENDENTAL APPROACH IN LEGAL AID CONCEPT IN INDONESIA: A PHILOSOPHY OF LAW PERSPECTIVE
}

\author{
Muhamad Akhsanul Fadli \\ Law \& Philosophical Justice Community, Balikpapan, Indonesia \\ *Email: akhsanulfadli@gmail.com
}

\begin{abstract}
Legal aid in Indonesia, especially in terms of access to justice, legal aid provided by the state to the people still relies on positive law. The law governing legal aid in Indonesia still revolves around the number of cases and the budget absorption target given to legal aid institutions that have been verified and accredited by the state for people/groups in need. Verification and Accreditation from the state with the parameters written in the law prevent those who need legal assistance if they are not categorized as poor. The requirement of the poor to access legal aid implies that access to legal aid for everyone in conflict is far from fair. Access to legal aid is very important because the goal of law is justice. In addition, legal aid aims to provide justice for those who do not have legal knowledge, in other words, are blind to the law. Justice for all is the pulse of legal aid that cannot be separated from the right to legal aid
\end{abstract}

The Indonesian Journal of International Clinical Legal Education DOI: https://doi.org/10.15294/ijicle.v3i4.48293

Submitted: Dec 12, 2020 Revised: March 13, 2021 Accepted: August 10, 2021 Available online at https://journal.unnes.ac.id/sju/index.php/iccle

(C) 2021 Authors. This work is licensed under a Creative Commons AttributionShareAlike 4.0 International License (CC BY-SA 4.0). All writings published in this journal are personal views of the authors and do not represent the views of this journal and the author's affiliated institutions. 


\section{Muhamad Akhsanul Fadli}

for those in need. Legal aid can be managed by the community, legal aid institutions/institutions that should provide access to those who need legal assistance and those in dispute, both poor and rich, so that justice for all is achieved. This study discusses the transcendental dimensions of legal aid. This study uses a descriptive research method that aims to analyze legal aid from aid agencies seen from the study of legal philosophy and legal aid with a transcendental dimension.

\section{Keywords: Justice; Legal Aid; Transcendental Justice, Philosophical Jusctice}

\section{INTRODUCTION}

The implementation of legal aid in Indonesia was initially aimed at those who are economically disadvantaged. Thus, to obtain legal aid as regulated in the legal aid law, every person or group must be categorized as poor. Any person or group who is not poor cannot access the legal aid budget from the government. Only a part of the Indonesian people are poor, but many are considered incapable, weak, oppressed, or very deficient in many aspects but are not poor administratively in accordance with the terms, conditions, and parameters that have been determined by the state in the legal aid law.

Legal aid for the poor in the legal aid law has not been able to cover the poor, the weak and the needy, who struggle before the law and desperately need legal assistance compared to the poor who are in conflict with the law. Positive laws promulgated by the state in legal aid law cannot be separated from human values and justice, which results in not being able to cover those who need legal assistance, even though according to the constitution everyone is equal before the law. The concept of free positive law in facilitating those in need and those in difficulty is the weakness of legal aid which cannot provide legal aid to everyone who sociologically needs legal aid unless legal aid can only be given to the poor.

Law is very closely related to justice, some even argue that law must be combined with justice so that it is truly meaningful as law because the purpose of law is to create a sense of justice in society. In every applicable law, there is a demand for justice. Law without justice is meaningless and has no value in the eyes of society. Combining law and justice is easier said than done. However difficult it is, this effort 
must be made for the sake of the state and jurisdiction because basic legal rights are recognized by the judiciary. ${ }^{1}$

An order of law and justice cannot be enforced without regard to justice because justice describes the true meaning of law and justice. Because the purpose of the state and law is to achieve the peak of happiness for its people, thinking about law is closely related to the idea of how justice and order can be realized. ${ }^{2}$ Law is formulated as a set of rules consisting of norms and sanctions. ${ }^{3}$ It should be noted that the law is a protector of human interests, while human interests are always developing, dynamic, both in type and quantity. Thus, the law must be dynamic so that it is in line with the development of human interests so that human interests that continue to develop can always be protected. ${ }^{4}$

The weaknesses of legal positivism block normative truth, as well as criticism of sociological legal thought (quantitative and interpretive), although at a certain point it is value-free, understands reality and leaves it as it is, and is impartial. This encourages some people to present legal science that supports humanitarian goals as a critical theory so that legal science does not only serve the interests of the status quo behind valuefree claims but more than that. ${ }^{5}$

Laws that are only formed in the realm of mere logic will be a problem because the norms formed by them rely solely on human reason. In such circumstances, the norms to be built will be contrary to the actual norms. Because the norms of justice will conflict with positive legal norms, in the end there will be a difference between the actual value of justice and the law that was built. Because positive legal norms are formulated based on human reason, it is impossible to fully reflect the actual reality, thus giving rise to values in the realm of metaphysical and rational values. ${ }^{6}$

Meanwhile, according to Teguh Prasetyo in his book entitled 'The Dignified Justice Perspective of Legal Theory' states that the law to create a dignified society is law - including in this case the regulation of legal aid for those in need - humanizing humans. This means that the law treats and upholds human values in accordance with the nature and purpose of life. Humans are noble creatures of God as stated in the second

1 M. Agus Santoso. Hukum, Moral Dan Keadilan: Sebuah kajian Filsafat Hukum, Jakarta: Prenadamedia Group, 2012, pp 86-87.

2 Muchsin. Kekuasaan kehakiman Yang Merdeka Dan Kebijakan Asasi. Jakarta: STIH IBLAM, 2004. pp 74-75.

3 C.S.T. Kansil. Pengantar Ilmu Hukum Dan Tata Hukum Indonesia, Jakarta: Balai Pustaka, 1984. pp. 38-39.

4 Sudikno Mertokusumo. Teori Hukum, Yogyakarta: Cahaya Atma Pustaka, 2014, pp. 25-26.

5 Widodo Dwi Putro. Kritik Terhadap Paradigma Positivisme Hukum, Yogyakarta: Genta Publising, 2011, pp. 1-2.

6 Budiono Kusumohamidjojo. Filsafat Hukum: Problematik Ketertiban yang Adil, Bandung: Mandar Maju, 2011, pp. 143-144. 
principle of Pancasila, just and civilized humanity, which includes recognition of human dignity with all rights and obligations and obtains fair treatment of humans, oneself, the environment, and God. ${ }^{7}$

Efforts to discuss legal, religious, ethical, and moral issues in depth will support the results of the development of legal science. Therefore, to study and understand the law, it is necessary to put more emphasis on things that are substantial and transcendental on the basis of social facts that cannot be separated from religious, ethical, and moral values. ${ }^{8}$ To achieve the ideal law, humans are required to always think-coqito ergo sum-I think, therefore I exist. Thus, Rene Descartes poetically philosophizes about human existence. ${ }^{9}$ Human nature is thinking because it is the superiority of humans and the ability to think is only possessed by humans, not by other living creatures. ${ }^{10}$

Legal aid in a dignified society appears as an embodiment of the values of humanity and justice that are absorbed and regulated in the legal aid law so that everyone can access legal aid from the state. Legal aid for the poor as regulated in the law does not cover those who are unable, weak, and in need, having disputes before the law, thus losing its essence as a means of helping those in need. Surah An-Nisa Verse 75 which means "And why do you not want to fight in the way of Allah and (defense) the weak, both men, women and children who pray, "Our Lord, get us out of this land (Mecca) whose inhabitants were unjust. Give us protection from Your side, and give us help from Your side." Weak people are not only economically incapable but can be in the form of discrimination and oppression. Therefore, defending in the sense of providing legal assistance to people who are weak and in need of legal assistance is a call to carry out God's commands. Then in Surah Al-Asr verses 1-3 which means "By time, indeed, humans are in loss, except for those who believe and do good and advise one another to truth and advise one another to patience." Carrying out Allah's commands to do good deeds, advice to obey the truth, and advice to be patient are transcendental legal concepts.

Transcendental law in the development of legal science emphasizes the integration between law and religion that occupies science according to the postmodernism movement. In this case, science is understood in a broader scope, including ethical, moral, and spiritual values of religion.

7 Teguh Prasetyo. Keadilan Bermartabat Perspektif Teori Hukum, Bandung: Nusa Media, 2015, pp. 109-110.

8 Absori. Hukum Dan Dimensi Spiritual: Perspektif Positivis, Pospositivis dan Spiritualisme, dalam PROFETIKA, Surakarta: Magister Pemikiran Islam Program Pascasarjana Univesitas Muhammadiyah, Jurnal Studi Islam Vol. 7 No. 2 Tahun 2005.

9 Muhammad Nur Islami. Hukum Dan Kebebasan Berpikir, Yogyakarta: Pustaka, Pelajar Offset, 2015, pp. 1-3.

10 Musa Asy'arie, Rekontruksi Metodologi Berpikir Profetik, Yogyakarta: Lembaga Studi Filsafat Islam (LESFI), 2016, pp. 1-5. 
This is where religion plays an important role in efforts to understand law and legal science in a broad or holistic perspective. From a historical perspective, postmodern law offers spiritual value as a result of the spiritual crisis in modern law. The law offered emphasizes not only formal and procedural law but more broadly with the unity of knowledge that connects the law with empirical facts and the values contained include ethical, moral, and spiritual values. ${ }^{11}$

Kuntowijoyo's idea to reintegrate science and religion gave birth to the concept of prophetic science. The prophetic paradigm consists of four important values as its foundation; humanization, liberation, transcendence, and historical activism. These four values, apart from being a critical framework, also underlie the idea of emancipation - from individual transformation through faith and humanization, to the transformation of knowledge through the liberation of Islamic knowledge and scholarship, to social transformation through historical activism. Thus, the interests of the prophetic paradigm are humanization, liberation, and transcendence and freedom in historical activism, which are not bound to contribute and are not forced to do something. ${ }^{12}$

According to the Big Indonesian Language Dictionary at the Language Center, transcendentalism is: 1. emphasizing spiritual things; 2 difficult to understand; 3 invisible; 4 abstract, so the law in this theory is based on spiritual values that are difficult to understand and abstract. Transcendental law cannot be separated between its physical body (formal) and its transcendental value. The justification sought for transcendental law is only for the sake of justice based on truth under the rule of Allah SWT, the Controller of life. ${ }^{13}$ Considering the explanation above, the writer is interested in studying legal aid in the transcendental dimension. Transcendental as Kuntowijoyo's perception is based on three aspects; humanization (amar ma'ruf), liberation (nahi munkar), and transcendence (faith). These three points are the concept of legal aid which is expected to provide justice for all people based on human values. ${ }^{14}$

11 Absori. Epistimologi Ilmu Hukum Transendental dan Implementasinya dalam Pengembangan Program Doktor Ilmu Hukum, Proseding Seminar Nasional Pengembangan Epistimologi Ilmu Hukum, Program Doktor Ilmu Hukum Universitas Muhammadiyah Surakarta, 2015, pp. 34-49.

12 Absori, Kelik Wardiono, Saepul Rochman. Hukum Profetik: Kritik Terhadap Paradigma Hukum Non Sistematik, Yogyakarta: Genta Publishing, 2015, pp. 1-3.

13 Absori. Pemikiran Hukum Transendental dalam Konteks Pengembangan Ilmu Hukum Indonesia, dalam Transendensi Hukum Prospek dan Implementasi, Yogyakarta: Genta Publishing, 2017, pp. 32-33.

14 The concept of transcendental justice emerged from the chaotic judiciary in Indonesia which was triggered by judges' decisions which played more in legal rhetoric, formalities and used normative legal logic (positivism) so that many judges' decisions were controversial and difficult to meet the expectations of justice seekers. In addition, there are many existing concepts of justice, in which the implementation and determination of the benchmarks of justice also vary. Seeing this phenomenon, 
Muhamad Akhsanul Fadli

\section{LEGAL AID AND THE HUMANITY VALUES}

Legal aid must be a right for all Indonesian people, regardless of rich or poor, capable, or incapable, strong or weak, even majority or minority, so that the state protects the entire Indonesian nation and the entire homeland of Indonesia and in the context of promoting general welfare, educating people's lives. nation, and participate in carrying out world order based on independence, eternal peace, and social justice as stated in the Preamble to the 1945 Constitution of the Republic of Indonesia. Protection for all Indonesian people is also inseparable from the right of Indonesian citizens to obtain legal assistance without conditions. Article 27 paragraph (1) of the 1945 Constitution states "All citizens are equal before the law and government and are obliged to uphold the law and government with no exceptions". It was emphasized that there is no difference in obtaining the right to legal aid for Indonesian citizens. However, in its elaboration, as regulated in the legal aid law, it is stated that legal aid is provided free of charge to people or groups of the poor, as stated in Article 1 point 1 and Article 1 point 2 of Law Number 16 of 2011 concerning Legal Aid.

Legal aid for the poor eliminates the rights of those who need legal assistance, those in need, the poor, minorities, and even those in conflict with the law from their right to obtain legal aid from the state if they cannot prove their requirements as recipients. The parameters determined by the state for those who are categorized as poor are also lacking in their implementation so that they are not able to reflect the values of justice and humanity mandated in the legal aid law. Recipients of legal aid are considered poor if they can prove the administrative requirements (see Figure 1).

\footnotetext{
there is a discourse on the idea of upholding prophetic justice in realizing transcendental justice based on the thought of integrating judges based on prophetic intelligence in deciding a case into an alternative that can be considered to be able to meet the expectations of justice seekers. See Fanny Dian Sanjaya, "Legal Aid in Indonesia: A Study of Legal Aid with a Transcendental Dimension." Journal of Transcendental Law Vol. 2 No.2, 2020, pp. 83-99; Siti Kasiyati, "Law Enforcement in Indonesia in Perspective of Transcendental Legal Justice Paradigm." Journal of Transcendental Law Vol. 2 No.2, 2020, pp. 100-114. Please also compare with Ingrid Robeyns, "Are transcendental theories of justice redundant?." Journal of economic methodology Vol. 19 No.2, 2012, pp. 159-163.
} 


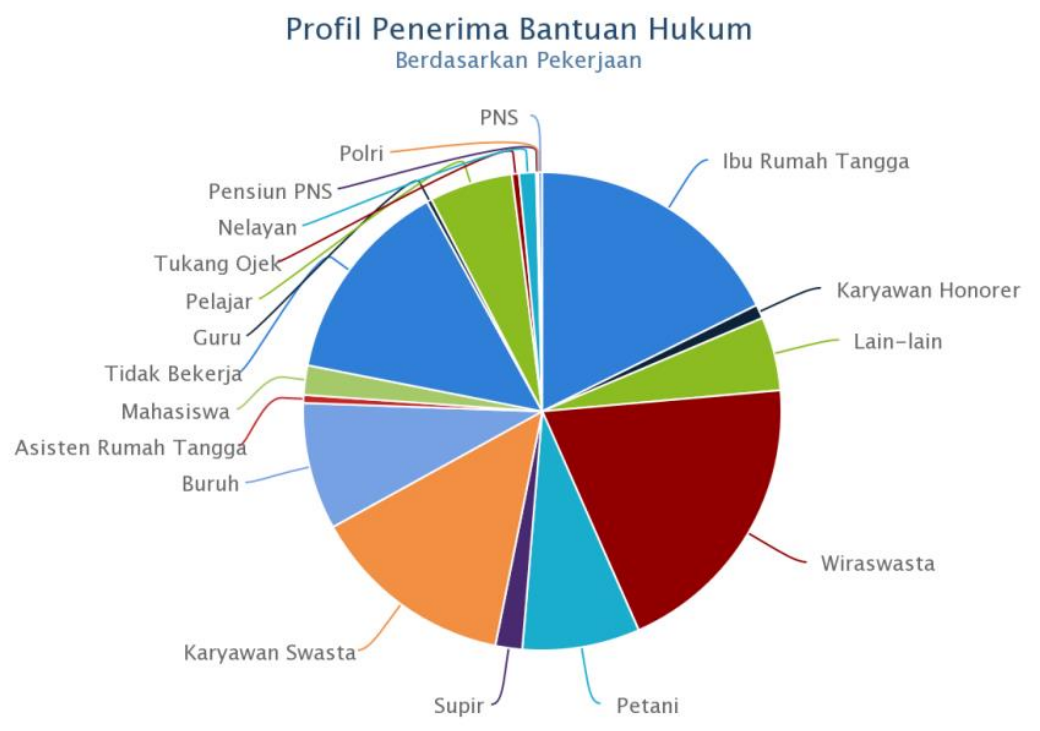

Figure 1. Legal Aid Recipient Profile

Based on the data on legal aid recipients who have been grouped by occupation above, the occupations of legal aid recipients are very diverse, ranging from retired civil servants, civil servants, teachers, police, to fishermen, motorcycle taxi drivers, farmers, drivers, scavengers, household assistants, students, laborers. , private employees, entrepreneurs, temporary employees, and so on. Thus, it is very difficult to conclude that the recipients of legal aid are poor people or groups of poor people. The poor have no income to meet their basic needs. Retired civil servants, civil servants, teachers, and the police certainly have a steady income and can meet their basic needs. Obviously, it's unfair to those who can't afford to deal with the law. Indeed they need legal assistance but are not considered poor.

The right to legal aid which is limited to a person or group of poor people is contrary to the purpose of the legal aid law itself as stated in Article 3 letter $b$ "to realize the constitutional rights of all citizens in accordance with the principle of equality in the law". The principle of equality before the law in the context of the right to legal aid which is limited to the poor cannot guarantee the rights of all citizens who need legal assistance, including those who need legal assistance, as long as those in dispute in the law are weak, oppressed, poor, and marginalized. and not declared poor by the state.

The definition and purpose of legal aid differs in each era as regulated in the applicable laws and regulations. In general, legal aid is addressed to every person who is incapacitated on humanitarian grounds. During the Dutch colonial era, legal aid was regulated in Article 250 of the Herzien Inlandsch Reglement (HIR) Reglemen Indonesia (RIB) which reads "If the defendant is ordered to appear before a judge for a 
crime punishable by the death penalty, and the defendant, both in examination by the public prosecutor who regulated in paragraph six of article $83 \mathrm{~h}$, then states his desire so that in the trial he is assisted by a legal expert or legal expert, then to provide such assistance the chairman in his decision appoints a member of the district court, a legal expert, or an employee with a law degree or other legal expert who agrees. In order to carry out the work, the appointment may also be made by means of a separate decree during the examination in court. it is not finished if the suspect declares the intention, but the appointment does not occur if there is no legal scholar or legal expert at the district court who agrees, then the legal scholar employee or other expert legal expert appointed by the district court provides legal assistance free of charge." Free legal aid is only for those sentenced to death provided that the legal assistant agrees to do so.

In 2003, in line with the enactment of the law on advocates in Law Number 18 of 2003 in Article 1 point 9 it was stated that legal aid is legal services provided by advocates free of charge to those who cannot afford it. In 2011, the legal aid law was passed. Legal aid is a service provided by legal aid providers free of charge to beneficiaries as stated in Article 1 point 1 of Law Number 16 of 2011 concerning Legal Aid. The right to legal aid has been universally accepted as guaranteed in the International Covenant on Civil and Political Rights (ICCPR). Articles 16 and 26 of the ICCPR guarantee that everyone is entitled to the protection of the law and must be protected from all forms of discrimination. Meanwhile, Article 14 paragraph (3) of the ICCPR provides conditions related to Legal Aid: 1) the interests of justice, and 2) the inability to pay advocates. Free legal aid provided by legal aid institutions/organizations including advocates is free, meaning that legal aid recipients do not pay a penny to obtain free legal aid that is their right.

The right to legal aid is also contained in Article 18 of Law Number 39 of 1999 concerning Human Rights Article 18 paragraph (4) that everyone who is brought to court has the right to legal assistance from the start of the trial until the decision has permanent legal force. made by the court and Article 54 of Law Number 8 of 1981 concerning the Criminal Procedure Code that for the sake of defense, a suspect or defendant has the right to obtain legal assistance from one or more legal advisers during and at each stage of the examination, according to the procedures regulated in law. This law and Law Number 48 of 2009 concerning Judicial Powers in Article 56 paragraph (1) state that everyone who is litigating matters is entitled to legal assistance and paragraph (2) the State bears the costs of the case. for justice seekers who cannot afford it, both in the Criminal Procedure Code and the Judicial Powers Law, this assistance is the right of every person and the state bears the costs for justice seekers who cannot afford it. they are also not limited by poor conditions to be entitled to legal aid. 


\section{THE TRANSCENDENTAL DIMENSION OF LEGAL AID}

Nowadays legal issues are increasingly complex, technology and science are growing, poverty rates are decreasing along with reforms. Most Indonesians are no longer poor. People with middle-income economies who are not poor or unable to pay for the services of an advocate, are oppressed, marginalized, and minorities do not receive legal assistance from the state when in conflict with the law while they need legal assistance. Thus, the concept of pro bono legal aid emerged which is an obligation for advocates to carry out their legal aid obligations. The concept of pro bono legal aid is aimed at those who need legal assistance but cannot afford the services of a lawyer. Then for those who are considered poor by administration, the concept of state legal aid for the poor emerged. This means that legal aid is given to the poor with a budget from the state, not directly from lawyers or legal aid agencies.

According to Schuyt, Groenendijk, and Sloot as quoted by Soerjono Soekanto in his book entitled "Bantuan Hukum Suatu Tinjauan Sosio Yuridis". There are five types of legal aid: ${ }^{15}$

1) Preventive legal assistance ("preventive rechtshulp") is legal counseling and legal counseling to the wider community.

2) Diagnostic legal assistance ("diagnostic rechtshulp") is legal advice commonly known as legal consultation.

3) Legal aid for conflict regulation ("conflictregularend rechtshulp") is legal aid to address concrete legal issues (Note: this legal aid is known as legal aid for underprivileged or poor citizens, socially and economically)

4) Legal aid for the formation of law ("rechtsvormende rechtshulp") is to generate jurisprudence that is firm, precise, clear, and true.

5) Legal assistance for legal reform ("rechtsverniewende rechtshulp"), including efforts to enforce legal reform through judges or legislators (in material arrangements).

Based on the types of legal aid mentioned above, the concept of legal aid emerged. The existing concepts of legal aid, such as structural legal aid, pro bono legal aid, and free legal aid, are no longer able to cover those who need legal assistance. The concept of structural legal aid, for example, was motivated by the fact that most of the people at that time were poor and did not understand the law. Most of the poor were unable to participate in political and economic roles, resulting in a gap between the majority of the poor and the power that existed at that time, resulting in an imbalance of relations.

15 Soerjono Soekamto. Bantuan Hukum Suatu Tinjauan Sosio Yuridis, Jakarta, Ghalia Indonesia, 1983, pp. 27-38. 


\section{Muhamad Akhsanul Fadli}

The concept of structural legal aid according to Adnan Buyung Nasution means a series of programs, either through legal channels or other acceptable means, which are directed at changing relationships that will become the basis of social life towards more equal relationships. This is a prerequisite for developing laws that provide justice for the vast majority of the poor in Indonesia. That is, the concept of structural legal aid was developed in order to build a just and prosperous society. ${ }^{16}$

Legal aid activities in Indonesia vary, although it is specifically defined as the activities of an advocate in the litigation process. Legal aid is one of the organizations in the legal system that provides practical legal guidance. If in the judicial environment, the judge is the key figure who will give the final decision and in the legal aid organization the lawyers/advocates offer alternative reasoning beyond that proposed by their fellow lawyers or advocates from the opposing party (in civil cases/state administration) or by the prosecutor (in criminal cases). ${ }^{17}$

The existence of law bearers is fundamental in law enforcement, they must find correct, civilized, and fair legal decisions. Law bearers are not justified in viewing articles as material for consideration, but also must examine the social and humanitarian dimensions of a case. In theory, it must have a starting point, namely the relationship between humans and the law. The lower the theoretical basis of the regulation, the more it will be considered as a closed formal-legalistic unit. On the other hand, the more the theory shifts to humans, the more open it becomes and touches the social issues of humanity. ${ }^{18}$

In an article entitled "Legal Aid: Modern Themes and Variations", Cappelletti and Gordley describe several legal aid systems, both in Europe and America. They state that there are two models (systems) of legal aid, which are then called the juridical-individual model and the welfare model. That is, on the one hand, legal aid can be considered as a right granted to citizens to protect individual interests and on the other hand, as a right to welfare which is part of the social protection framework provided by the welfare state. ${ }^{19}$

Everyone has the same right to obtain legal assistance, to obtain justice because it has been guaranteed by the 1945 Constitution. This right for everyone is called welfare. Legislation on legal aid must provide justice in terms of access to legal aid which is the right of everyone, regardless of social status, to protect all. Moreover, legal aid is a right for those in need. It is considered fair if legal aid as a right is given by the state to legal aid recipients who are not in a poor condition as regulated

16 Adnan Buyung Nasution. Bantuan Hukum Di Indonesia, Jakarta: LP3ES, 1981, pp. 292-293.

17 Shidarta. Hukum Penalaran dan Penalaran Hukum, Yogyakarta: Genta Publishing, 2013, pp. 291-293.

18 Widodo Dwi Putro. Op.Cit. pp. 11-12.

19 Soekanto, Op.Cit. p. 11. 
in the legal aid law. Legal aid providers are social institutions or legal aid agencies. In Islamic organizations, for example, the perspective used is different from legal aid in the existing positive law. The concept of legal aid in general is to help those who need legal assistance and especially Muslims who are in disagreement so that truth and justice can be upheld. Legal aid also serves to provide legal assistance to members of the organization, including providing legal assistance to assets of social organizations which later become disputes or objects of legal disputes at any level.

Based on the concepts of legal aid above, such as structural legal aid, pro bono legal aid, free legal aid, it can be seen that there is a shift in the need for legal aid that is beyond the reach of existing legal aid, even its definition. and goals begin to shift. In the past, structural legal aid was aimed at the poor. Pro bono legal aid for the poor is based on the subjective assessment of advocates and free legal aid for the poor using state funds. This shift occurs because the legal assistance needed today is not only for the poor but also for everyone in conflict with the law. Criteria for legal aid recipients, background in providing legal aid, purpose of legal aid, legal aid budget are no longer determined by the laws and regulations governing existing legal aid but are also a form of obligation to facilitate human beings in the field. ethical, moral, and spiritual or transcendental values.

Beyond that, the law is attached to the entity of faith: divinity, because at the beginning of a law the words "By the Grace of God Almighty" are always written, or in a Court Decision which reads "For the sake of justice, belief in one and only God". This gives rise to the perception that law is synonymous not only with justice but also with the sacredness of "Divinity". However, in the end, we are trapped in a reality that we construct as a paradox when we see that law does not represent justice or even divinity. ${ }^{20}$

The development of the need for legal aid in Indonesia has given birth to a new dimension of legal aid, namely legal aid in a transcendental dimension. This is because the existing legal aid, such as structural legal aid, free legal aid, and pro bono legal aid, is no longer able to reach those in need. Legal aid for those who are not poor has created and mobilized Islamic organizations to assist the state in providing legal aid. Legal assistance provided by Islamic organizations is a transcendental dimension. The transcendental dimension of legal aid arises because the law cannot cover the need for legal aid. The concept of legal aid also uses an approach to ethical, moral, and spiritual values which should be a source of law governing legal aid.

From the outset, legal aid has a transcendental dimension because legal aid is aimed at helping those in need. This assistance is provided by

20 Antonius Cahyadi. Hukum Sebagai Teks: Penanda Yang Kosong, dalam Sosiologi Hukum dalam Perubahan, Jakarta: Yayasan Obor Indonesia, 2009, pp. 290-291. 
legal aid providers such as legal aid agencies and community organizations. Assistance from both community organizations and legal aid institutions is technically carried out by advocates. Advocates have a professional code of ethics in carrying out their profession. In addition, advocates swear or swear by their respective beliefs before carrying out their profession to help those who are in dispute and need legal assistance. The oath or oath of an advocate before carrying out his profession, including providing legal assistance, is pronounced with "In the name of Allah I swear", making this legal aid a transcendental dimension from the start. Advocates who have sworn and pledged to their God before carrying out the legal aid profession become part of a social organization or legal aid institution that provides legal aid. The Oath or Oath to Defend God embodies a transcendental dimension in carrying out professional duties, including providing legal assistance. They will always act honestly, fairly, and responsibly according to law and justice because their oaths/promises receive direct spiritual supervision from God.

The transcendental dimension of legal aid provided by Islamic organizations, for example in providing legal aid, is based on humanitarian values and unconditional justice which indicates that the recipient is poor. The Muhammadiyah organization provides legal assistance to its members, mustad'afin, Muslims, or anyone in need through the Legal Aid Institute under Muhammadiyah Higher Education as a form of community service and through the Muhammadiyah Legal Aid Institute as a form of application of the Qur'an and sunnah of the Prophet. Legal assistance provided to its members, fellow Muslims or mustadafin, is not solely for those in need but is based on moral and spiritual values in carrying out religion and the obligations of Allah and the Messenger.

LBH Muhammadiyah was formed to create legal order in the nation and state, ensure justice and human values inside and outside Muhammadiyah. Basic Legal Aid Services in the field of Law and Human Rights are organized based on values derived from the Qur'an and the Sunnah of the Prophet as well as Muhammadiyah regulations. The principle of legal aid services is carried out with the principles of justice, progress, sincerity, honesty, trustworthiness, professionalism, transparency, accountability, concern for the poor, and balance that combines knowledge, faith, and charity.

The concept of legal aid for Islamic organizations and Muhammadiyah organizations that have LBH Muhammadiyah uses the concept of legal aid with a transcendental dimension in providing legal advice. Muhammadiyah is a legal organization that is also an Islamic movement, Da'wah Amar Ma'ruf Nahi Munkar (enforcing what is right and forbidding what is wrong.) and Tajdid (reform), according to the Qur'an and Sunnah. So the concept of legal aid also comes from the 
Qur'an and the Sunnah of the Prophet. The legal aid provided is such as "Constitutional Jihad" and "Human Jihad" (jihad means to struggle) so that it is legal aid with a transcendental dimension.

According to Roger Garaudy, transcendental or transcendence is interpreted in three perspectives; first, recognizing human dependence on the Creator. Being content with oneself and viewing man as the center and measure of all things is contrary to transcendence. Transcendence transcends human instincts, such as greed and lust for power. Second, transcendence means acknowledging the continuity and common measure between God and man, implying that transcendence is parallel to power, wealth, and knowledge. Third, transcendence means recognizing the superiority of absolute norms that transcend human reason. ${ }^{21}$

Transcendental thinking can be seen in a wider range, in the form of spiritual, ethical, and moral. Spirituality, ethics, and morality are no longer understood in one aspect, namely aspects related to theological issues and desires that are seen through doctrine and prayer, but more than that. The issue of these values can intersect with the development of science, social, culture, economics, and law. Transcendental scholars propose the value and meaning behind it so that it appears that the building of science is more open and complete in addressing the problems of life. In this case, transcendental thinking begins to speak irrationally and metaphysically (emotions, feelings, intuition, values, personal experiences, speculations), moral and spiritual aspects as part of understanding science. ${ }^{22}$

Muhammadiyah plays a role in providing legal aid as God's call for humanity and unconditional justice which refers to individuals as poor. Muhammadiyah defends mustad'afin with humanitarian jihad in handling cases or with constitutional jihad at the level of judicial review through LBH Muhammadiyah under Muhammadiyah College. Legal aid is given not only because they deserve legal assistance but it is based on moral and spiritual values in practicing religion and God's command to humanize humans by doing good deeds, giving advice to obey the truth, and upholding justice on earth. Allah teaches to help those who are needy or poor with the zakat of material. So, the first concept of helping humans, Muslims in solving legal problems with legal assistance also helps from the immaterial side. The second concept is that along with the times, many other Islamic organizations provide legal assistance to other Muslims, Islamic figures/activists, members of conflicting mass organizations, assets belonging to disputing Islamic organizations, as well as the foundation of the Islamic organization itself in the event of a change in legislation. applicable. Cases that have attracted public

21 M. Fahmi. Islam Transendental, Menelusuri Jejak Jejak Pemikiran Islam Kuntowijoyo, Yogyakarta: Pilar Religia, 2005, p. 97.

22 Absori, Op.Cit. p. 15. 
attention, such as the 212 Movement (Action for Defending Islam) due to the blasphemy of the Qur'an, the Death of the Suspected for the Crime of Terrorism, the late. Siyono before the trial, and the Imam of the Islamic Defenders Front, needed a transcendental approach in providing legal assistance.

The concept of legal aid with a transcendental dimension is legal aid to everyone in need as a manifestation of the absorption of spiritual and ethical values. Justice and humanity are at the core of transcendental law which is implemented in legal aid. Legal aid is given to anyone, including mustad'afin, the poor, minorities, and the marginalized, not limited to the right to legal aid only to poor people or groups of people as regulated in the legal aid law. Transcendental legal aid not only humanizes humans by providing legal aid rights as the main effort when dealing with the law but also contains humanitarian and justice goals. The ethical, moral, and spiritual values of religion in legal aid are expected to be able to provide justice. Humanitarian and fair legal aid that is carried out will provide its own spirit for legal aid actors because it is the embodiment of God's command to help fellow human beings through legal aid and do justice by providing legal aid to those in need.

\section{CONCLUSION}

This paper concludes that the implementation of legal aid in Indonesia still refers to positive laws that are only given to the poor. However, in practice, not only the poor can access legal aid, so that the legal aid regulated in the legal aid law becomes ineffective. Legal aid is a right that must be granted to all persons in conflict with the law regardless of status; rich, incapable, oppressed, marginalized, or poor so that it is fair for every Indonesian who is in conflict with the law, whether the plaintiff, defendant, victim, witness, or perpetrator. To understand legal aid, its substance must be studied in depth, which cannot be separated from spiritual, ethical, and moral values. Legal aid contains the essence of helping other humans who are experiencing legal difficulties or dealing with the law. Law is primary in nature. Everyone in conflict with the law aims to seek justice. Justice is a basic human need that is desired by everyone regardless of the status of rich or poor. Justice is the main aspect of human needs, as stated by Daniel Webster "Justice is the great interest of the people of the earth". Allah teaches humans through His Prophet and His Messengers to help other humans who are in conflict. Finally, the concept of legal aid that contains a transcendental dimension to everyone is inherent in transcendental values and can be applied to legal aid in Indonesia. The concept of legal aid with a transcendental dimension is a concept that is currently needed to complement the concepts of individual legal aid, structural legal aid, pro bono legal aid, and existing legal aid for poor groups/communities. 


\section{REFERENCES}

Absori, A. (2015). Epistimologi Ilmu Hukum Transendental dan Implementasinya dalam Pengembangan Program Doktor Ilmu Hukum, Proceedings, Seminar Nasional Pengembangan Epistimologi Ilmu Hukum, Program Doktor Ilmu Hukum Universitas Muhammadiyah Surakarta.

Absori, A. (2017). "Pemikiran Hukum Transendental dalam Konteks Pengembangan Ilmu Hukum Indonesia," dalam Transendensi Hukum Prospek dan Implementasi, Yogyakarta: Genta Publishing.

Absori, A., Wardiono, K., \& Rochman, S. (2015). Hukum Profetik: Kritik Terhadap Paradigma Hukum Non Sistematik. Yogyakarta: Genta Publishing.

Asy'arie, M. (2016). Rekontruksi Metodologi Berpikir Profetik. Yogyakarta: Lembaga Studi Filsafat Islam (LESFI).

Cahyadi, A. (2009). Hukum Sebagai Teks: Penanda Yang Kosong, dalam Sosiologi Hukum dalam Perubahan. Jakarta: Yayasan Obor Indonesia.

Fahmi, M. (2005). Islam Transendental, Menelusuri Jejak Jejak Pemikiran Islam Kuntowijoyo. Yogyakarta: Pilar Religia.

Kansil, C.S.T (1984). Pengantar Ilmu Hukum Dan Tata Hukum Indonesia. Jakarta: Balai Pustaka.

Kasiyati, S. (2020). Law Enforcement in Indonesia in Perspective of Transcendental Legal Justice Paradigm. Journal of Transcendental Law, 2(2), 100-114.

Kusumohamidjojo, B. (2011). Filsafat Hukum: Problematik Ketertiban yang Adil. Bandung: Mandar Maju.

Mertokusumo, S. (2014). Teori Hukum. Yogyakarta: Cahaya Atma Pustaka.

Muchsin, M. (2004). Kekuasaan kehakiman Yang Merdeka Dan Kebijakan Asasi. Jakarta: STIH IBLAM.

Nasution, A. B. (1981). Bantuan Hukum di Indonesia. Jakarta: LP3ES.

Putro, W. D. (2011). Kritik Terhadap Paradigma Positivisme Hukum. Yogyakarta: Genta Publising, 2011.

Robeyns, I. (2012). Are transcendental theories of justice redundant?. Journal of economic methodology, 19(2), 159-163.

Sanjaya, F. D. (2020). Legal Aid in Indonesia: A Study of Legal Aid with a Transcendental Dimension. Journal of Transcendental Law, 2(2), 83-99.

Santoso, M. A. (2012). Hukum, Moral Dan Keadilan: Sebuah kajian Filsafat Hukum. Jakarta: Prenadamedia Group. 


\section{Muhamad Akhsanul Fadli}

Shidarta, S. (2006). Karakteristik Penalaran Hukum dalam Konteks Keindonesiaan. Bandung: CV Utomo.

Soekanto, S. (1983). Bantuan Hukum Suatu Tinjauan Sosio Yuridis. Jakarta: Ghalia Indonesia.

[...] Kamus Besar Bahasa Indonesia online, https://kbbi.kemdikbud.go.id/entri/transendental

[...] SID Bankum - BPHN, https://sidbankum.bphn.go.id/

\section{Conflicting Interest Statement}

All authors declared that there is no potential conflict of interest on publishing this article.

\section{Funding}

None

\section{Publishing Ethical and Originality Statement}

All authors declared that this work is original and has never been published in any form and in any media, nor is it under consideration for publication in any journal, and all sources cited in this work refer to the basic standards of scientific citation.

Cite this article as:

Fadli, M. A. (2021). Transcendental Approach in Legal Aid Concept in Indonesia: A Philosophy of Law Perspective. The Indonesian Journal of International Clinical Legal Education, 3(4), 465-580. https://doi.org/10.15294/ijicle.v3i4.48293 